\title{
A HISTORY OF THE FATAL ACCIDENT ACTS
}

\section{Richard Kidner, Professor of Law, University of Wales, Aberystwyth.}

It is often said that the introduction of the Fatal Accidents Act 1846 was one of the great law reforming measures of the last century but it will be suggested that the proposers of the Act were confused in their objectives and that a century and a half later there are still problems with how to compensate for death. ${ }^{1}$ Commonly known as Lord Campbell's Act, the original Bill in 1845 was not even introduced by him but by Lord Lyttleton, while Lord Campbell dealt with the related issue of deodands. Furthermore it was not until a late stage in the Bill's progress that it was amended to provide compensation to the relatives of the deceased, a point now regarded as the essence of the provision. Subsequently the Act was amended no less than seven times, and over the years the pressure for liberalising the law has been constant. The purpose of this article is to show that the proposals were not fully thought through at the time and that the complexities of compensation for fatal accidents were not properly understood and it is hoped to link the initial failure with problems that became apparent later. This will involve a study of the origins and purposes of the original Act together with its early interpretation.

However before looking at the Act itself it is necessary first to explain two legal issues which prompted the reform of 1846. The first is the rule in Baker $\mathrm{v}$ Bolton $^{2}$ to the effect that a living plaintiff cannot sue for the death of another, and the second is the law of deodands by which articles which cause death could be seized by the Crown. Much of the pressure for change was the need to reform deodands and it may well have been the essential quid pro quo for the directors of railway companies to agree to the new system, for they felt they had suffered grievously at the hands of juries who sought to punish railway companies by seizing railway property or imposing substantial levies.

\section{THE RULE IN BAKER V BOLTON}

This seems to have been a 'rule' which suddenly appeared from nowhere, was still argued about a century later, was generally considered to be wrong and yet which remained the law. This decision of 1808 was not reported until 1833 by Lord Campbell himself who might later have wished that he had left it in his drawer of "bad Ellenborough law". 3 The case itself concerned an action by the plaintiff husband for the death of his wife in a coaching accident and he claimed that he "had wholly lost and been deprived of the comfort, fellowship and assistance of his said wife and had from there hitherto suffered and undergone great grief, vexation and anguish of mind". So far this seems to be an action for bereavement but he also claimed that as he was a publican his wife had been of great assistance to him in his business which perhaps indicates some economic loss. The decision of Lord Ellenborough at Nisi Prius occupies only six lines and he merely said that "in a civil court the death of a human being

${ }^{1}$ For the present difficulties see Law Commission Consultation Paper No 148, "Claims for wrongful death," and Waddams "Damages for Wrongful Death: Has Lord Campbell's Act outlived its usefulness?” (1984) 47 MLR 437.

2 (1808) 1 Camp 493; 170 ER 1033. See Holdsworth, "The origin of the rule in Baker v Bolton" (1916) 32 LQR 431.

3 See Atlay, The Victorian Chancellors Vol 2 p 138. The collection perished in the Temple fire of 1838 . 
could not be complained of as an injury". ${ }^{4}$ No reasons were given and in 1873 in Osborn v Gillett ${ }^{5}$ Bramwell B doubted the accuracy of the report ${ }^{6}$ and said, "no argument is stated, no authority cited and I cannot set a high value on that case". The majority however felt that the rule had been acquiesced in for many years and was supported by the fact that the law needed to be amended by the Fatal Accidents Act in 1846.

The technical justification advanced to support Baker v Bolton was the supposed rule that the civil action merged in the felony and ceased to be available to a civil plaintiff. This was derived from Higgins v Butcher, ${ }^{7}$ a case of 1607, where it was said that "it is now become an offence to the Crown, being converted into felony, and that drowns the particular offence and private wrong offered to the master before, and his action is thereby lost." This seems not to have been questioned in the context of fatal accidents ${ }^{8}$ until the mid-nineteenth century where it was firmly declared that the rule merely suspended but did not destroy the civil action. This was even so in Osborn v Gillett $^{9}$ where the majority denied the felony merger rule but seemed to support Baker $\mathrm{v}$ Bolton mainly on the basis of its longevity. A similar view was taken in Clark v London General Omnibus $\mathrm{Co}^{10}$ where the action was for funeral expenses ${ }^{11}$ and loss of a daughter's services, and again it was held that there was no action either under the statute or at common law, Lord Alverstone saying that to allow recovery by those who had incurred expenses as a result of the death would go too far.

So far as the common law is concerned the matter was finally put to rest by the decision of the House of Lords in the Admiralty Commissioners $\mathrm{v}$ S.S. Amerika ${ }^{12}$ where the Admiralty claimed for the capitalised value of the pensions which they had to pay to the relatives of the crew of the

${ }^{4}$ However the plaintiff recovered $£ 100$ damages for his own injuries and "the distress of mind he had suffered on her account from the time of the accident till the moment of her dissolution." Lord Campbell adds a note asking "If the wife had been killed on the spot is this to be considered damnum absque inuria." This difficulty was to some extent dealt with later by the action for loss of expectation of life.

5 (1873) LR 8 Ex 88 . The case concerned an action by the plaintiff for the death of his "daughter and servant", claiming special damage for the loss of her services. The Fatal Accidents Act did not apply to the death of a servant and thus was not applicable to this element of the damage pleaded.

6 Bramwell B questioned why there was no reference to the special damage caused to the plaintiff's business and why he was allowed to recover for distress of mind at all.

7 (1607) Yelv 89: 80 ER 61. For a discussion of this and subsequent cases see Malone, "The Genesis of Wrongful Death" (1965) Stan LR 1043.

${ }^{8}$ There were cases which discussed the rule, for example in relation to trover when the thief had not been prosecuted. See Gimson v Woodfull (1825) 2 CaP 41; 172 ER 19, overruled in White v Spettigue (1845) 13 M \& W 603; 153 ER 252. See also Wells v Abrahams (1872) LR 7 QB 554 where Lord C.J. Cockburn said "it has long been established as the Law of England, that where an injury amounts to an infringement of the civil rights of an individual and at the same time to a felonious wrong, the civil remedy, that is the right of redress by action, is suspended until the party inflicting the injury has been prosecuted."

9 (1873) LR 8 Ex 88.

10 [1906] 2 KB 648.

11 Funeral expenses incurred by dependants could not be claimed until the law was changed by the Law Reform (Miscellaneous Provisions) Act 1934.

12 [1917] AC 38 
submarine B2 which was sunk by the negligence of the defendants. The main argument was that Higgins $\mathrm{v}$ Butcher ${ }^{13}$ was wrong to say that the civil action merged with the felony but Lord Parker said that even if the rule had been misconstrued, nevertheless Baker $\mathrm{v}$ Bolton must be adhered to. This was so even though "whatever may have been thought in the early part of the seventeenth century, or even in Lord Ellenborough's day, it is now quite clear that the rule only suspends and does not require the destruction of the civil remedy", and it was also said that Higgins v Butcher $^{14}$ was not based on any rule of public policy but merely on the nature of an action in trespass. Thus, "however anomalous it may appear to the scientific jurist" it was too late to change a rule which had been recognised for so long.

It seems clear therefore that the rule in Baker $\mathrm{v}$ Bolton was based on a misunderstanding and when this was discovered it was too late to recover the situation. Very little is said in any of the cases about any possible sound justification for the rule and while the proposers of the Fatal Accidents Act 1846 wanted to abolish the rule, they were not very clear about who should be able to sue and what should be included in the damages. It might be noted that the cases which occurred after 1846 mainly dealt with the problem of employers claiming for loss of services of an employee. The common law did permit an action by an employer for being deprived of services when the servant was injured (the action per quod servitium amisit) ${ }^{15}$ but whatever the technical arguments about Baker $\mathrm{v}$ Bolton might have been the courts were adamant that this principle should not extend to cases of death. Had Baker v Bolton been overturned the common law would have had to face the very difficult task of deciding the scope of actions on death, a debate which is still going on at the parliamentary level a century and a half after the passing of the Fatal Accidents Act 1846.

\section{DEODANDS}

The Fatal Accidents Act 1846 cannot be seen in isolation for it was intimately bound up with the abolition of deodands. ${ }^{16}$ Blackstone referred to deodands as "whatever personal chattel is the immediate occasion of the death of any reasonable creature: which is forfeited to the king..."17 In fact the thing which caused the death was not necessarily forfeited nor did it always go to the Crown. ${ }^{18}$ It seems that often the coroners' juries settled on a monetary sum to be forfeited and as a concession this was often paid to the relatives of the victims, so the statement by Lord Campbell in 1846

13 (1607) Yelv 89; 80 ER 61.

14 Ibid: Lord Sumner however took the view that historically it was true that the trespass merged into the felony whatever the modern view might be.

15 The action only applied in cases of a menial servant, IRC v Hambrook [1956] 2 QB 641, and was abolished by the Administration of Justice Act 1982, s2.

16 See for example the second reading of the Fatal Accidents Bills of 1845 where Lord Campbell says that the Deodands Abolition Bill is suspended, but that the two bills are dependent on each other. Hansard vol lxxix col. 1053 (April 21 1845).

17 Commentaries vol 1 p 299. Note also Bracton "Omnia quae movent ad mortem sunt Deo danda."' This does not seem to require such immediate causation as Blackstone. Blackstone referred to both Mosaic and Athenian law as being origins of this practice.

18 For the law and practice of deodands see Smith, "From Deodands to Dependency" (1965) 11 Am Jnl Legal History 389 and Sutton, "The Deodand and Responsibility for Death" (1997) 18 Legal History 44 
that "any pecuniary mulct that might be inflicted would go to the Crown" 19 was probably not what usually happened but understandable in expounding the vagaries of deodands.

Deodands had tended to be given low values by juries but the advent of the steam engine meant that it was difficult for juries to pretend that the deodands had little value and awards became highly variable. ${ }^{20}$ Extreme examples include a levy of $£ 2000$ upon the London and Birmingham Railway in $1841^{21}$ and $£ 1500$ upon the owners of the S.S. Victoria in $1838,{ }^{22}$ but Smith concludes that the fears of employers were unfounded as there was no rule which ever required juries to make realistic assessments or to follow precedents, and the fear that there would be repetitions of the $£ 2000$ deodand had little to substantiate it. Nevertheless there was a worry that deodands would be too severe, or at least that was given as a reason for replacing them by compensation to relatives. ${ }^{23}$

If, however, one reason for abolishing deodands was the vagaries of coroners' juries and the danger of property actually being seized, deodands as a system could also be inadequate from the point of view of the relatives of the deceased. Not only did they receive money as a concession and not as of right, but also decisions of coroners juries to levy a deodand were often overturned leaving the relatives with nothing. Thus one of the reasons for abolition was said to be that they were "hard to effect for procedural reasons", ${ }^{24}$ one example of the problem being The Queen v Polwart ${ }^{25}$ where a jury had levied a deodand of $£ 800$ upon the S.S. Manchester but this was overturned by Lord Denman on the ground that deodands only applied in cases of misadventure and not in cases of murder or manslaughter. ${ }^{26}$

It, therefore, seems that a number of interests had good reason to see the end of deodands and their replacement by a more rational system. Deodands were haphazard in their operation, they might be set at excessive levels (but often were not), and it was not clear who was entitled either to make the levy or receive the benefits. On the other hand their abolition might cause the loss of some revenue to the Crown (it was not certain how much) ${ }^{27}$ However it was equally clear that deodands could not be abolished without replacement for they represented in many cases the only deterrent to see that proper care was taken by entrepreneurs. Indeed one of the problems with the Fatal Accidents Act was that it was

19 Hansard vol lxxxv col 967 April 61846.

20 For a study of deodands at this time see Cawthon, "New Life for the deodand: Coroner's inquests and occupational deaths in England 1830-46." (1989) 33 Am Jnl Legal History 138.

21 Smith, op cit p.396.

22 Cawthon, op cit $\mathrm{p} 147$.

23 See Lord Campbell in the debate on the 1845 bill: Hansard vol lxxvii col 1027 (Feb 24 1845).

24 Hansard vol lxxxvii col 1365 (July 22nd 1846).

25 [1841] 1 QB 819; 113 ER 1345.

26 This case is described by Cawthon, op cit as "an example of the venom which coroners courts could exercise among high court judges" but that may be a little harsh: see the next case in the reports, The Queen v West (1841) 1 QB 826 where Lord Denman ordered a deodand even though there was some objection to the description of the owner. Note also The Queen v Brownlow (1839) 11 Ad\&E 119; 113 ER 358 and The Queen v The Grand Junction Rly (1839) 11 Ad\&E128; 113 ER 362.

27 One estimate was $£ 800$ - $£ 900$ with the Corporation of Liverpool losing a similar amount: see The Times August 121846. 
justified largely as a replacement deterrent and little thought was given to who should be compensated or why.

\section{THE PASSING OF THE BILLS}

From what has been said above it seems that one of the major reasons for introducing the Fatal Accidents Bills was the problem of deodands: these had the potential to be expensive for entrepreneurs while at the same time not providing any consistent or rational system of compensation for victims, while development of the common law was blocked by the rule in Baker $\mathrm{v}$ Bolton. Accordingly deodands had to be abolished but the rule in Baker $\mathrm{v}$ Bolton could not simply be abrogated for that would open up too wide a field of potential litigants, including employers of those killed.

The general structure of the 1845 and 1846 Bills was similar but they differed considerably in detail and both differed from the Act as finally passed. All three versions begin by stating that whereas no action was maintainable for causing the death of another "it is often times right and expedient that the wrongdoer in such a case should be answerable in damages for the injury so caused by him", and go on to impose liability by saying that the person who would have been liable if death had not ensued shall be liable notwithstanding the death of the person injured. This at least made it clear that the class of potential defendants was not being changed although there had been suggestions that the scope of vicarious liability and the liability of public bodies should either be clarified or expanded. ${ }^{28}$ The Act and the 1846 Bill then say that this shall be so even though the death would have been a felony, thus ensuring that the problems of Baker $\mathrm{v}$ Bolton are overcome. ${ }^{29}$ The next provision as to who can claim is different in all three versions. The 1845 Bill refers to the action being for the benefit of "the wife or husband, or child or children of the deceased", whereas in 1846 this had changed to "such person or persons as are entitled to the personal effects of the deceased". This of course was very different as the dependants might have received nothing at all. However at the Committee stage this was changed back but the class of those who could claim was considerably expanded so as to cover the wife, husband, parent, grandparents, step-parents, children, grandchildren and stepchildren. As we shall see who can claim, and how they should be defined, has been a matter of debate ever since.

A small oddity in the Bills is that both say that the action shall be brought in the name of the executor but only the 1845 Bill added that if there was no executor then the claimants themselves could sue. This latter point was omitted from the Act but had to be put right by the Fatal Accidents Act Amendment Act 1864. ${ }^{30}$

It has often been said that it was the initiation of the railway age that led to a demand for compensation for families of victims of accidents. It is true that except in the sphere of employment ${ }^{31}$ accidental sudden death would have been fairly uncommon in the 1830's and no doubt public disquiet at the number of fatalities on the early railways would have brought this problem home to the middle classes. In fact while railway accidents were

28 See for example (1845) 9 Justice of the Peace 209 where it is suggested that turnpike trustees should be liable for the negligence of road repairers.

29 The 1846 Bill uses the word "manslaughter" rather than felony whereas the 1845 Bill omits this point altogether.

30 This point is discussed below.

31 See generally Bartrip and Burnam, The Wounded Soldiers of Industry (1983) and Cornish and Clark, Law and Society in England (1989) ch.7. 
quite common and safety standards lax, the number of fatalities was not as high as one might have thought, ${ }^{32}$ but this no doubt is an area where perception was more important than fact. In 1870 the Report of the Select Committee on Compensation for Accidents ${ }^{33}$ thought that the introduction of the Fatal Accidents Act "did not arise from anything connected with railway accidents in particular" although in evidence ${ }^{34}$ James Blenkinsop, secretary to the London North Western Railway, thought that "it was railway accidents that brought the thing prominently before the public". To say therefore that the Act was brought about by railway accidents is only half true: the Select Committee thought it was due to a feeling that the rule of non liability for death "rested upon no sound foundation", but it was the evidence of railway accidents which brought about the feeling that something ought to be done. Indeed it is probably no coincidence that the examples of the potential operation of the Act given during the debates in the House of Lords were mainly based on railway accidents, but disquiet was also felt on behalf of mine owners. ${ }^{35}$

The story of the Bills ${ }^{36}$ begins in 1845 when Lord Lyttelton presented his Fatal Accidents Bill on February 18, and Lord Campbell the Deodands Abolition Bill on February 24. Lord Campbell referred to the fact that deodands were too severe and complained that "everything which in the remotest degree contributed to the death was included in the forfeiture". This may have been an exaggeration but perhaps referred to the vexed question of whether only a part or the whole of a complex set of machinery was liable. ${ }^{37}$ However when the Fatal Accidents Bill was read a second time on April $21^{38}$ he said that the Deodands Bill was "suspended" and hoped that it would "go pari passu with this Bill and that their march would be triumphant through the other House". The interdependence of the two Bills is also indicated by the fact that in 1846 both Bills were taken together at second and third readings in the House of Lords, and in 1845 Lord Campbell had said ${ }^{39}$ in relation to Lord Lyttleton's Bill that it was "a most signal amendment of the law... indeed he should hardly venture to abolish the system of deodands, however absurd, until there was some check upon negligence substituted". Furthermore in 1846 Lord Denman said ${ }^{40}$ that "as deodands were the only security now against death being caused by reckless conduct, the abolition was a strong argument in favour of the other Bill". The Fatal Accidents Bill passed the Lords on June $17^{41}$ but finally collapsed in the Commons when the votes were 39 against and only 7 for. ${ }^{42}$ It is unclear why this came about but in the next year Lord Campbell did make the point ${ }^{43}$ that

32 It is said that the number of passengers killed in 1843 was 27 , for 1844 it was 14, and for 1845 it was 13: see Kostal Law and English Railway Capitalism (1994) p281.

33 Session Papers 1870 vol. X p207.

34 Ibid Qu.7.

35 See the comments by Sir J. Graham in the House of Commons: Hansard vol lxxxvii col 1365 (July 22 1846). However the doctrine of common employment solved their problems.

36 A full account is given in Bartrip and Burnam, op cit pp 97-103.

37 See Smith, "From Deodand to Dependency" (1967) 11 Am Jnl Legal History 389 at 395.

38 Hansard vol lxxix col 1053 (April 21 1845).

39 Ibid.

${ }^{40}$ Hansard vol lxxxvi col 174 (May 7 1846).

41 Hansard vol lxxxi col 632 (June 17 1845). There was no debate.

42 Hansard vol lxxxii col 1130 (July 25 1845).

43 Hansard vol lxxxv col 967 (April 6 1846). 
his 1846 Bill might be opposed in the Commons by directors of railway companies, and he hoped "that they will forget they are directors". The railway interest in parliament was a formidable force ${ }^{44}$ and they had recently played a significant part in Gladstone's Railways Bill of $1844,{ }^{45}$ but there is no real evidence that it was they who killed off the 1845 Fatal Accidents Bill. However during the passage of the 1846 Bill the Law Times pointed out ${ }^{46}$ that "some of the railway interests are about to employ their influence in the Commons to defeat [the Bill] as they succeeded in doing last year". However the fact remains that it was the AttorneyGeneral who moved the motion against the Bill and the number of members who voted was small, perhaps indicating a lack of interest in the subject.

The next year both the Deodands Abolition Bill and the Fatal Accidents Bill were put forward by Lord Campbell. ${ }^{47}$ During the second reading he noted that other countries provided a remedy, and allusion was made to the role of solatium in Scottish law, a point which was to prove difficult when the Act came to be interpreted by the courts when claims were made for damages for bereavement. ${ }^{48}$ It also became clear that the problem was the rule in Baker $\mathrm{v}$ Bolton which it was said was based on the merger of the civil action with the felony, a point which was also made in the Act itself for the preamble states that the Act is to apply "although the Death shall have been caused under such Circumstances as amount in Law to Felony".

By the third reading in the House of Lords ${ }^{49}$ there was little debate except a comment by Lord Campbell that if the Lord Chancellor were injured in a railway accident the company would be extremely sorry as it would have to compensate him but that if he were killed "they would not care one farthing" as the law could afford no remedy. ${ }^{50}$ It was perhaps this that led Sir Frederick Thesiger in the Commons ${ }^{51}$ to complain that "no explanation had been given of [the Bill] except some pleasantries that had occurred elsewhere between two noble and learned Lords as to the losses of one and the profits of the other". He also referred to it as a "careless and hasty" Bill but it may be assumed that he knew what he thought it meant, as indeed he was to say often in cases in which he appeared during the next decade. Again there was little debate in the Commons except references again to the Scottish law of solatium, but by the time it returned to the Lords there had been a significant amendment. As originally proposed the

44 See generally Alderman, The Railway Interest (1973) who states that in 1847 there were 80 MPs in the railway interest (41 Liberal, and 39 Tory).

45 This became the Railways Act 1844, 7 \& 8 Vict. c85 and is mainly known for its provision of cheap or 'parliamentary' trains.

46 The Law Times, May 21846.

47 House of Lords, first Reading of both Bills on April 7 1846: Hansard vol lxxv col 651.

48 This issue is discussed below. It was also noted that the main reason advanced against the Bill was that the value of a life was so great that nothing could be compensation for it, but this gave rise to no debate about what test of compensation there was to be.

49 Hansard vol lxxxvi col 173 (May 7 1846).

50 The Lord Chancellor replied "there is a much more difficult case to estimate for compensation than the one which my noble and learned friend has had the kindness to suggest. If my noble and learned friend should unfortunately fall a sacrifice, how would any jury be able to estimate the value of his hopes". This may have been intended to be rude but at least it indicates an appreciation of the problems of compensation for future loss.

51 Hansard vol lxxxvii col 1365 (July 22 1846). 
compensation was to be paid to the estate rather than to be divided up between the family of the victim. This was significant because if paid to the estate there was no guarantee that the dependants would benefit for there was then no protection as now provided by the Inheritance (Provision for Family and Dependants) Act $1975^{52}$ if the estate is diverted away from the dependants by the will. Again this suggests that the problems of compensation had not really been thought out.

The debates on the Bills are not very illuminating and perhaps justify the view that the issues were not fully thought out. The principal motive seems to have been the abolition of deodands and their replacement by an adequate system of deterrence so that an enterprise which kills rather than injures should not avoid having to pay. How much and to whom was not really thought about and indeed it is remarkable how little stir the passage of the Bill caused either in Parliament or beyond. In 1845 The Times ${ }^{53}$ commended the Fatal Accidents and Deodands Abolition Bills saying that "it will be well to get rid of deodands, taking care however to provide a remedy against negligence and which will be all the better, if while it punishes the guilty it relieves the innocent....", and that "it is more reasonable and more in accordance with the spirit of the age that if an accident occurs... the compensation which would be paid to the sufferer if he survived should be paid to the family if he dies, than that this aggravation of the injury should divert it altogether into another and stronger channel under the form of a deodand". Perhaps the common view was that the reform was so obvious that little need be said, especially as at that time there was beginning to be concern about railway accidents and the regulation of railways. However, not even the Law Times bothered to take much notice of the Bill perhaps because the incidence of accidental death was not high enough to bring much business to the legal profession. Certainly the Law Times was at that period much exercised by the Recovery of Small Debts Bill which provided for recovery of debts up to $£ 20$ in reformed county courts and where legal representation would only be allowed with the consent of the judge..$^{54}$ The only comment of the Law Times was on May 21846 when they said that "the topics of the week have been wholly without interest for the profession" 55 but noting "the two excellent measures of Lord Campbell for abolishing the antiquated absurdity of deodands and introducing the principle long since recognised in the jurisprudence of the continental countries - compensation for death by accident to the families of those for whose service that death was incurred".

52 On this point see Waddams, "Damages for wrongful death: has Lord Campbell's Act outlived its usefulness?" (1984) 47 MLR 437. The amendments were accepted by the House of Lords on Aug 21 1846: see Hansard vol lxxxviii col 926.

53 April 231845 p5 col e.

54 The Law Times claimed that their opposition was not merely a matter of self interest but that "hundreds of courts would be presided over by incompetent judges" and that the measure would increase the incidence of "sham" attorneys, that is those who threatened others with legal proceedings even though they were not lawyers. The Law Times regularly exposed such people.

55 A similar attitude seems to have been held by the government for on July 16 1846 Lord Russell said "there are many other Bills which are not of great importance which we propose to go on with...". 
The Justice of the Peace at least dedicated an editorial to the subject, albeit in $1845^{56}$ where it was referred to as "a most excellent bill" and "the public is in sympathy with the measure", and a suggestion was made to improve the vicarious liability of public bodies. Accordingly it seems that at the time nobody took much notice of the Bills and if they did, regarded them as an obvious reform. This of course was the time of the railway mania and much parliamentary time was taken up by railway bills and by "the battle of the gauges", but it seems remarkable that the legal profession did not see the potential of the Act nor did those who would be most affected make much trouble, perhaps believing that the abolition of deodands was a good price to pay. ${ }^{57}$ However even if the broad principle of the Bills was easily accepted it is odd that not much thought was given as to how this was to be implemented nor to the underlying philosophy or principle, and indeed these continued to cause problems for the next century and a half.

\section{INITIAL INTERPRETATION OF THE ACT}

The earliest case under the Act immediately raised the difficult question of bereavement. 58 During the parliamentary debates there had been much discussion of Scottish law which allowed both "patrimonial" loss (that is economic loss flowing from dependency), and "solatium" (that is reparation for feelings), 59 and indeed in the House of Commons the Attorney-General, although regarding the Bill as impractical, said that English law should go no further than Scottish law. ${ }^{60}$

The courts however had other ideas : the first case seems to have been Armsworth $\mathrm{v}$ South Eastern Railway ${ }^{61}$ where the deceased railway labourer was thrown off a truck by a violent jerk of the locomotive. ${ }^{62}$ Parke B mentioned Scottish and French law but gave no clear direction on the question of bereavement, although the widow had claimed for being deprived of "comfort, society, fellowship, assistance and support" as well as for funeral expenses. Parke B noted that this was the first case under the Act and said that both juries and judges "must be very much at sea on this subject until by a long course of decisions some settled principle can be established". He warned the jury against being blinded by matters of feeling and merely advised them to award "fair compensation", without saying anything specific about the heads of claim. ${ }^{63}$

56 (1845) 9 Justice of the Peace p 209: this was probably written by the editor, Charles Clark.

57 There had been murmurings during the debates on behalf of small enterprises, mine owners and the railways. Later, when railway safety had become a real problem and perhaps people had become more litigious the railways did complain. See further below.

58 For the modern debate on this issue see below.

59 See Walker, Delict (1966) vol 2 pp 722 et seq. See now the Damages (Scotland) Act s1(4).

60 Hansard vol lxxxvii col 1365 (July 22 1846).

61 (1847) 11 Jurist 758; 81 RR 918.

62 There was no mention of the doctrine of common employment in this case: the first such case seems to have been in 1850 and is discussed below. The accident in Armsworth happened when chalk was being removed from a fall in Merstham cutting in Surrey.

63 The jury awarded $£ 100$. The deceased earned $£ 52$ per year and had a life expectancy of 27 years. It seems therefore that the jury was hardly generous even on a purely economic loss basis, but in a sense the plaintiff was fortunate to recover at all in the light of the impending application of the doctrine of common employment. 
By 1849 the courts were clearer about the objectives of the Act, and in Gillard v Lancashire and Yorkshire Railway64 Pollock C B limited recovery to economic loss. During argument Sir Frederick Thesiger pointed out that the Chief Baron's view would mean that there could be no action for the death of a child and that such a death would rather be a benefit than otherwise to the parent. He declared, and as an active participant in the debates he should have known, that that was not the view of the Act by those who framed it. However Pollock C.B. declared that "it is a pure question of pecuniary compensation and nothing more which is contemplated by the Act....The poorest and meanest peasant who may lose nothing at all by the death of his wife is not entitled to sue....I think it is utterly impossible for a jury to estimate any sum as a compensation for the injured feelings of the survivors...the framers of the Act never could have meant to give compensation to the parent for the mere deprivation of his son, or the widow for that of her husband".

The cynical and hard hearted may agree that the death of a child is an economic benefit rather than a loss, but it seems a little presumptuous to tell Sir Frederick Thesigner what the framers of the Act intended, and the words of the statute by no means required this solution. Section 2 instructs the jury to give "such damages as they may think proportioned to the injury resulting from such deaths to the parties respectively....", and it may be thought that with all the talk of "solatium" that reparation for injured feelings and loss of society may well have been contemplated.

However the strict view was confirmed in Blake v Midland Railway, ${ }^{65}$ a case in which Lord Campbell himself was part of the bench, although it seems he was not present when judgment was delivered. ${ }^{66}$ The jury had awarded damages of $£ 4000$ and in attempting to support this Sir Frederick Thesiger again said that it was supposed that the law of England was being equated with that of Scotland. ${ }^{67}$ In his judgment Coleridge $J$ pointed out that the law of assythement (from which solatium was derived) was wholly alien to the common law and had not been introduced into English law. He noted that section 2 of the Act referred to "injury to the parties" which was more appropriate to "a loss of which some estimate may be made" and that if solatium were allowed it would be inappropriate to inquire into the degree of mental anguish of each member of the family. ${ }^{6}$ He also referred to the potential consequences to a small trader for the Act "applies not only to great railway companies but to little tradesmen who send out a cart and horse in the care of an apprentice" and concluded that if solatium were to have been available, more specific language should have been used: accordingly the claim must be limited to pecuniary loss.

64 (1849) 12 LT 356

65 (1852) 18 QB 93; 118 ER 35. This view was accepted in Ireland: see Condon v Great Southern and Western Railway (1865) IR 16 CL 413, Bourke v. Cork and Macroom Railway (1879) 4 LR Ir.682 and Gallagher v. Electricity Supply Board [1933] IR 558.

66 See 118 ER 35 at p40: the judgment was said to be that of the court although only Coleridge and J J Crompton were present.

67 Lord Campbell made few comments during the argument: he referred to deodands as a "strange peculiarity", and noted that evidence could be given if the removal of a father was a benefit to the family.

68 Then not only the child without filial piety, but a lunatic child and a child of very tender years, and a posthumous child on the death of the father, may have something for pecuniary loss, but cannot come in pari passu with the other children, and must be cut off from the solatium, see Coleridge J, 118 ER 35 at p 41. 
Whatever may have been in the minds of the promoters of the Act it is perhaps not surprising that, in the absence of clear words, ${ }^{69}$ a restrictive interpretation was adopted for the common law had never given any thought to grief, nor usually to loss of society. ${ }^{70}$ The fear of excessive damages was also clearly a problem, for Parke B had often referred to the fact that juries should not take the opportunity to punish railway companies by large awards. ${ }^{71}$ The result was not only to limit awards, but also, as was recognised, to leave some deaths wholly uncompensated. That is still a problem which has not been wholly solved by the token payments available today and, even though Scotland (and France) provided examples of solatium damages, it is not surprising that the ethos of the common law resisted such a change.

One of the earliest countries ${ }^{72}$ to introduce a form of solatium damages by statute was Ireland, which enacted in the Civil Liability Act 1961 section 49 a provision which added "reasonable compensation for mental distress resulting from the death to each of such dependants". ${ }^{73}$ However damages were not to be at large but were at that time limited to a maximum of $£ 1000$. In McCarthy v. Walsh ${ }^{74}$ it was said this did not mean that the judge should take $£ 1000$ as the worst case and then scale down the award proportionally, but rather should assess what is reasonable and then cap that.

It was not until $1973^{75}$ that the Law Commission in England and Wales recommended a limited right to damages for "bereavement", which was considered to be wider than grief but also included for example "the sort of loss which a man's wife and children suffer through the loss of his help as a member of the household and of his counsel as a husband and father". Nevertheless the award was only to be available to parents and spouses and was to be for a small fixed sum. ${ }^{76}$ However before the Law Commissioners' recommendations could be enacted the matter was considered again by the Pearson Commission in $1978^{77}$ which by a

69 Monkman, Damages for personal injuries and death $\left(9^{\text {th }}\right.$ ed, 1993) refers to this decision as "a piece of judicial legislation, quite unwarranted by the language of the statute". This may be a little hard as the statute in its terms was ambiguous.

70 Although Thesigner in argument did make a comparison with the action for enticing away a wife, which did cover damages for loss of society.

71 Armsworth v South Eastern Rly (1847) 11 Jurist 758; 81 RR 918. Parke B had also been the trial judge in Blake and although he said damages should be limited to pecuniary loss, he again left the case to the jury in general terms.

72 The first seems to have been South Australia in 1940: Law Commission Report No.56 para. 166 .

73 The introduction of this Act is fully discussed in Knight, "Damages under the Civil Liability Acts" (1965) Ir.Jur.34.

74 [1965] IR 246. See also Hubbard v. Rederij Viribus Unitis and Galway Stevedores (1966) 100 I.L.T.R. 40 where it was said that not everybody could claim but only those grievously affected by the death. The changes in England and Wales limited bereavement damages to specific classes.

75 Law Commission Report No.56, Report on Personal Injury Litigation Assessment of Damages.

76 The Law Commission's Draft Bill recommended $£ 1000$.

77 Royal Commission on Civil Liability and Compensation for Personal Injury. Cmmd 7054-1. 
majority ${ }^{78}$ agreed that there should be a small fixed sum ${ }^{79}$ which should be "directed at loss of society rather than at sorrow or suffering".

All this reform actively finally bore fruit in the Administration of Justice Act 1982, section 3 which amended the Fatal Accidents Act 1959 by allowing a claim for "bereavement". ${ }^{80}$ However it was not clear whether this meant grief alone or included loss of society and loss of services. It seems that only grief was contemplated as Lord Scarman was forthright saying "It is compensation for grief. It is not loss of society. It is loss of a person by death. It is very limited. It is very conventional. It amounts only to a recognition by the state that ... the fact of bereavement should qualify for some sympathetic recognition" ${ }^{81}$

This outline of the development of bereavement damages from 1846 shows the intractability of the problem on which strong views are held. It is not clear what was actually intended by the framers of the 1846 Act, although it is probably right to say that something akin to the Scottish system of solatium was assumed. It could be argued that as damages are incalculable no attempt should be made, which was the view taken by some MPs during the passage of the Act and by the judges after 1846. It may be that the function of the Act is only to ensure a future income stream for a dependant and any other compensation should be a matter for the individual prospective plaintiff to resolve by loss insurance. This would leave the law open to a charge of callousness and fails to do anything where, as in the case of children, the death has caused no economic loss. However in such cases it may not be the function of the law of tort to punish the wrong doer as the principle of corrective justice can only apply where "damage" has occurred and restitution is impossible in these cases even though a wrong has been done. However such a stance is probably politically unacceptable and the present pragmatic approach may endure whereby the wrong is recognised (and thus there is a public condemnation of the behaviour), but the compensation is merely a token. This has to be so even though one of the objectives of the 1846 Act was that death should not be cheaper than injury.

Some slight amelioration of the wholly restrictive interpretation of the Act was provided by acceptance of the idea that the Act covered not only existing pecuniary loss but could be extended to any reasonable expectation of such loss - i.e. prospective loss. For example in Franklin v.

78 Two members (Professors Schilling and Stevenson) dissented on the grounds there was no justification for compensation for non pecuniary loss by a fixed arbitrary figure. They said that "there will always be bereaved persons who regard such a payment as derisory" and as predicted this has turned out to be true.

${ }^{79}$ Which they thought should be set at half average annual industrial earnings (about $£ 2000$ in 1977) which would therefore be automatically adjusted in line with inflation.

${ }^{80}$ The claim is limited to a spouse or a parent of a deceased minor. The amount was originally set at $£ 3,500$ and was increased to $£ 7,500$ in 1990 . The Act also abolished the action for loss of expectation of life which had in some cases performed a function similar to that of damages for bereavement. For Northern Ireland see the Fatal Accidents (Northern Ireland) Order 1977 as amended by schedule 6 to the 1982 Act

${ }^{81}$ Hansard (H.L.) vol 428, col 1294 (30 March 1982). See also the comments of Lord Hailsham at col 1293 and the fact that a proposal to include unmarried minors was defeated as some such minors would be unaware of the loss (col 1298). 
South Eastern Railway ${ }^{82}$ the father of the deceased son was getting old and infirm and the son had been well disposed to assist him. Pollock C B said "we do not say that it was necessary that actual benefit should have been derived, a reasonable expectation is enough, and such reasonable expectation might well exist though from the father not being in need, the son had never done anything for him". Nevertheless an advantage might well have accrued to the father from the continuance of the life of son, and this could be claimed for. This view was the subject of some debate in Ireland. Although Condon v Great Southern and Western Railway ${ }^{83}$ had adopted the more liberal view, there were dicta in the later case of Bourke $\mathrm{v}$ Cork and Macroom Railway ${ }^{84}$ per Dowse B that there "must be evidence in existence at the time of the death of [the] son of a state of facts in connection with him out of which a pecuniary advantage arose or had formerly arisen and was likely to again arise...", 85 However these dicta were disapproved by the House of Lords in Taff Vale Railway v Jenkins ${ }^{86}$ which reiterated that the test was one of reasonable expectation of pecuniary benefit from a continuance of the life, and this view was eventually adopted in Ireland. ${ }^{87}$

One major restriction on recovery under the Act in the early years was the application of the doctrine of common employment. It has already been seen that no mention was made of this in $1847^{88}$ but 1850 saw its first use. ${ }^{89}$ In Hutchinson v York, Newcastle and Berwick Railway ${ }^{90}$ the deceased, employed by the defendants, was travelling on a train to South Shields when he was killed in a railway collision. The defendants successfully pleaded common employment. Alderson B said that "a master is not in general responsible to one servant for an injury occasioned by him by the negligence of a fellow-servant while they are acting in one common service", the argument being that each employee accepts the risks arising out of his work, including the risk of negligence committed by a fellow-servant. It has been pointed out ${ }^{91}$ that Hutchinson was a misapplication of Priestley $\mathrm{v}$ Fowler, ${ }^{92}$ the originating case of common employment and could have been distinguished from it on the ground that Priestley v Fowler was a case of the employer's personal liability whereas Hutchinson was a case of vicarious liability. Nevertheless the doctrine was affirmed by the House of Lords in 1858 in Barton's Hall Coal Company v Reid ${ }^{93}$ where Lord Cranworth thought the doctrine to be well settled. The effect was to severely limit the effectiveness of the Fatal

\footnotetext{
82 (1858) 157 ER 448.

83 (1865) IR 16 CL 413.

${ }^{84}$ (1879) 4 LR Ir. 682.

85 However Palles C B did not go so far and adopted the more usual view.

86 [1913] A C 1.

${ }^{87}$ Horgon v Buckley (No.1) [1938] IR 115. Note also Hull v Great Northern Railway of Ireland (1890) 26 LR Ir.289. The whole issue is fully dealt with in Knight, "Damages under the Civil Liability Act" (1966) Ir.Jur.35.

88 Armsworth v South Eastern Rly (1847) 11 Jurist 758; 81 RR 918.

89 On Common Employment generally see Ingman "The Rise and Fall of the Doctrine of Common Employment" [1978] Juridical Review 106 and Bartrip and Burman, The Wounded Soldiers of Industry (1983) pp 103 - 106.

90 (1850 5 Ex 342; 155 ER 150.

91 Ingman, op cit $\mathrm{p} 114$.

92 (1837) $3 \mathrm{M} \& \mathrm{~W} 1$; 150 ER 1030.

93 (1858) 3 Macq 266; 111 RR 896.
} 
Accidents Act ${ }^{94}$ and no doubt calmed the fears of the mine owners whose interests had been advocated during the debates on the Bill.

A further limitation of the Act derived from a defect in its structure, for section 2 required that the action must be brought "by and in the name of the executor or administrator of the person deceased", and this became a procedural and expensive problem for those whose estates did not justify proceeding to probate. This was remedied in 1864 by the Fatal Accidents Act Amendment Act ${ }^{95}$ which provided that if there is no executor or if there is one but he has not acted within six months of the death, then the persons entitled under the Act may begin an action in their own names.

It seems therefore that the original objectives of the proposers of the Act were somewhat muddled, concentrating mainly on the idea that with the abolition of deodands some form of deterrence must be put in place. Regrettably the compensatory aspects of the issue were hardly considered and when the matter came to be decided by the courts they took a narrow view. The restriction of damages to pecuniary loss and the application of the doctrine of common employment considerably limited the applicability of the Act, and while the procedural reform of 1864 brought about some relief, there were still many difficult problems to be tackled.

\section{THE REACTION OF RAILWAY COMPANIES}

Although the Fatal Accidents Act affected all businesses, its greatest effect was on the railway companies and it was they who took steps to change the law. Although railway litigation, both in relation to injuries and deaths, was fairly slow to expand, by the mid 1850 s it had become a serious problem for the companies. ${ }^{96}$ Their principal complaints were that the damages bore no relation to the fare paid and that juries were biased against the companies and awarded exorbitant damages.

As to the first point the companies said that they could not limit the damages by contract and they charged the same fare whatever the risk. One railway solicitor ${ }^{97}$ pointed out in 1870 that "the consideration does not bear any relation to the risk" and that the fare was the same whether the passenger was an unmarried bachelor with a low income or a wealthy businessman with a large dependent family. It was said that ${ }^{98}$ in one case the proportion of the fare due to the North London Railway was less than one penny and that they had to pay compensation of $£ 2300$. Reference was often made to Pym v Great Northern Railway 99 where damages of $£ 13,000$ were awarded by a jury ${ }^{100}$ to the widow and eight younger children of a rich businessman. The solution proposed by the companies was to limit the damages and provide means for passengers to purchase

94 The doctrine of common employment was partially abrogated by the Employers Liability Act 1880 and wholly by the Law Reform (Personal Injuries) Act 1948.

$9527 \& 28$ Vict. Cap.95. Strangely both the 1845 and the 1846 Bills had dealt with this problem for they both allowed the beneficiaries under the Bill to begin an action if there was no executor. It is not clear why this provision should have been omitted from the Act. The 1846 Act also provided that a payment into court may be made by a lump sum and need not be apportioned between the claimants.

96 For a lengthy discussion of the problem see Kostal, Law and English Railway Capitalism ch7.

97 James Blenkinsop, solicitor to the LNWR. Select Committee on compensation for accidents, 1870, session papers vol x, Qu 27.

98 Ibid. Qu 30.

99 (1863) 4 B \& S 403; 122 ER 508.

100 Reduced to $£ 10,000$ on appeal. The costs were $£ 2,000$. 
their own insurance. This was accepted both by the Royal Commission on Railways in $1867^{101}$ and by the Select Committee on Compensation for Accidents in $1870^{102}$ who recommended levels of $£ 1000$ for First class, $£ 500$ for Second class and $£ 300$ for Third. Nothing resulted from these proposals. It is interesting to note that the judges saw no objection to such a scheme ${ }^{103}$ and indeed there already was such a statutory arrangement with one railway company. In the early 1860 s the London Chatham and Dover Railway wished to build its "City Extension Lines" into London which involved the destruction of much housing for the poor and in return for permission to clear these houses the railway was required to run Workmens Trains at a special reduced rates, which in practice was oneseventh of a penny per mile. In return for that it was agreed that there should be a limit on damages as otherwise, it was claimed, the service would be uneconomic. ${ }^{104}$ Accordingly section 137 of the London Chatham and Dover (New Lines) Act 1864 said that "the liability of the company under any claim to compensation for injury or otherwise in respect of each passenger shall be limited to the sum of $£ 100$, and the amount of compensation payable in respect of any passenger so injured shall be determined by an arbitrator to be appointed by the Board of Trade and not otherwise". This is a remarkable provision to find in a local Act as it applied only to the LCDR and is an interesting example of the theoretical bargain which can be made in relation to compensation, ${ }^{105}$ but it is rare even on an industry-wide basis in relation to personal injuries ${ }^{106}$ except by international convention.

The other complaint of the companies was that juries were excessively generous when faced with a railway company and the 1870 Select Committee recommended that such cases should be tried by a special tribunal without juries. This was partly because of "the great amount of litigation which adds great expense to the amounts paid by the railway companies and not infrequently swallows up all the compensation which railway companies pay to sufferers". ${ }^{107}$ Again nothing was done.

These complaints were not specific to the Fatal Accidents Act but encompassed all personal injury litigation against railway companies, but their proposed solution and the economic reasons for it, provided an interesting discussion of how the risks should be distributed. It was said that compensation amounted to about $1 \%$ of gross receipts and $2 \%$ of working expenses, ${ }^{108}$ and although this was clearly manageable it highlighted the choice of full compensation and higher fares (or in the case

101 Session papers vol xxxviii, para 159. "We therefore recommend that on the one hand, railway companies should be absolutely responsible for all injuries arising in the conveyance of passengers, except those due to their own negligence, and that, on the other hand, the liability of the railway companies be limited within a maximum amount of compensation for each class of fares...".

102 Session papers vol x, p 207.

103 Bramwell and BB Martin ibid at Qu 860, although B Martin thought juries would award as much as they could within the maxima.

104 See generally the evidence of J S Forbes, general manager of the LCDR, to the Select Committee in 1870, op cit, Qu 1173.

${ }^{105}$ It was and is common of course for such bargains to be made in relation to the carriage of goods and indeed this was one of the railway companies justifications for this proposal.

106 An analogy might be made with some no fault accident schemes which limit liability, but where additional loss insurance is cheaply available.

107 Select Committee 1870 op cit para 159.

${ }^{108}$ Ibid. Para 159 and Qu 232 (James Blenkinsop). 
of the LCDR, no trains at all), and limits to compensation and loss insurance taken out by potential victims. That may be an issue which will have to be faced again if the "mania" of litigation of the 1860s against railways is repeated today in road or medical cases.

\section{INSURANCE COMPANIES AND INSURANCE BENEFITS}

A problem which had arisen at an early stage was the effect of accident insurance and life assurance on the amount of the damages. In 1857 Lord Campbell himself decided the issue in Hicks v Newport, Abergavenny and Hereford Railway ${ }^{109}$ when he charged the jury that they were first to deduct any sums paid by way of accident insurance and then also to deduct any life assurance premiums which would have been paid by the deceased. ${ }^{10}$ Nowadays such benefits are disregarded by virtue of the Fatal Accidents Act 1976, section 4 and this can no doubt be justified by the usual argument that the insurance payments are a result of the thrift of the deceased and should not go to the benefit of the tortfeasor. However the origin of the present rules lies not in that principle but in some rather odd goings on around the turn of the century. The story begins with the Railway Passengers Assurance Act $1864,{ }^{111}$ a private Act which in section 35 stated that "no contract of the company nor any compensation received or recoverable by the virtue of any such contract shall prejudice or affect any right or action claim or demand which any person may have against any other company or any person by virtue of [the Fatal Accidents Act 1846]." This meant that the company had considerable marketing advantages over other insurance companies since the payments under their policies would not be deducted whereas those of other companies would. It seems that in 1907 the Ocean Accident Insurance Company obtained a similar dispensation and about forty other companies were applying for similar exemptions. The Solicitor General said that it would not be expedient to repeal those private Acts of Parliament and the only course was to put all companies on the same footing. ${ }^{112}$ Accordingly the Fatal Accidents (Damages) Act 1908 provided that no account should be taken of any payments under contracts of assurance or insurance. The reform was thus based on no principle nor made out of concern for dependants or the wasted premiums paid by the deceased, but rather was based wholly on market manoeuvrings within the insurance industry.

\section{CONCLUSION}

The Fatal Accidents Act 1846 was the product of muddle and archaic common law defects but lacked principle. Many of the problems which exist today are due to this lack of underlying principles although a number of issues have been resolved during this century on a pragmatic basis. For example the range of claimants has been extended, ${ }^{113}$ but the issue of whether there should be a statutory list at all has only recently been

109 (1863) 4 B\&S 403; 122 ER 510. The case is reported as a note to Pym v Great Northern Rly.

110 This was because the family would have received the life assurance benefits anyway and merely benefited by their being paid earlier. This principle was approved by the House of Lords in Grand Trunk Rly of Canada v Jennings (1888) 13 App. Cas.800.

111 27-28 Vict. Cap cxxv s.35.

112 Hansard (H.C.) vol 192, col 259 (July 10 1908).

113 See the Law Reform (Miscellaneous Provisions) Act 1934 and the Fatal Accidents Act 1959. 


\section{Northern Ireland Legal Quarterly [Vol. 50, No. 3]}

debated. ${ }^{114}$ Another problem which has proved intractable is the effect of the potential re-marriage of a widow. ${ }^{115}$ Until $1971^{116}$ it was the practice of the courts to make a deduction for the chance that the widow might remarry and thus replace the lost support but that was changed in $1971^{117}$ although the anomalies thereby caused are apparent. ${ }^{118}$

Major theoretical problems have bedevilled the Act and yet it is seen as a necessary and highly valuable social welfare measure. It is here that the theoretical basis of compensation, pragmatism and public pressure meet, with some battles won and some lost. It has been suggested by some that the Fatal Accidents system should be done away with altogether and replaced by payments to the estate based on the lost years, the interests of the dependants being protected by the Inheritance (Provision for Family and Dependants) Act 1975. Waddams ${ }^{119}$ argues that the repeal of the Act would solve the problems of possible double recovery by the estate and the dependant, and the issue of a widow's prospects of re-marriage and the question of who should be regarded as a dependant. ${ }^{120}$ These views have been adopted by the Ontario Law Reform Commission ${ }^{121}$ but rejected by the United Kingdom Law Commission. ${ }^{122}$ However, whatever the virtues of such proposals, given the history of the Fatal Accidents Acts it would prove difficult to persuade the public that no direct payment should be made to dependants. Indeed many of the problems of the Fatal Accidents Acts do stem from the fact that it is seen as an independent right ${ }^{123}$ but that is thought right and proper. Whatever may have been in the minds of the

114 Law Commission Working Paper No.148 "Claims for Wrongful Death" para.3.36 where it is provisionally suggested that the list should be abandoned.

115 A related but dissimilar problem is the possibility of the widow returning to work. Such means of support is not in place of the husband's support for she may have been able to work in any event. Accordingly such possibility is ignored: see Howitt v Heads [1973] QB 64.

116 This practice may have been of fairly recent origin but seems to have been accepted by Lord Wright in Davies v Powell Dyffryn Collieries [1942] 1 All ER 657 at 663. See also Mead v Clarke Chapman [1956] 1 All ER 44.

${ }^{117}$ Law Reform (Miscellaneous Provisions) Act 1971. The common law rule has not been changed in Ireland where deductions are still made for prospects of re-marriage. See Fitzsimons v Telecom Eireann [1991] IR 536 at 549 and McDonagh v McDonagh [1992] IR 119.

118 The most commonly cited anomaly is that of the widow who has re-married by the time of trial. For an example see Thompson v Price [1973] 1 QB 838. There is also the fact that in action by a widower, prospects of re-marriage are taken into account, as are the prospects of a widow in calculating damages for the children, except that the children's maintenance will be included in the widow's damages.

${ }^{119}$ Waddam, "Damages for Wrongful Death: Has Lord Campbell's Act outlived its usefulness?" (1984) 47 MLR 437. See also Gammell v Wilson [1982] AC 27 at 80 where it is said that although the law is anomalous (because of recovery both by the estate and by the dependants) "the protection of the Fatal Accidents legislation has been with us for so long that I doubt whether its repeal would be welcomed". Incidentally the problem of "double recovery" was noted in the 1845 Bill where it was said that if the deceased had recovered compensation during his lifetime, the Fatal Accidents claim lapsed. That provision was not contained in the 1846 Bill nor in the Act.

${ }^{120}$ But that issue would still need to resolved with the succession legislation.

${ }^{121}$ Report on Compensation for Personal Injury and Death, 1987.

${ }^{122}$ Consultation Paper No 148, para 3.7.

${ }^{123}$ Albeit contingent on liability to the deceased. 
proponents of the 1846 (and that is very unclear) the fact remains that over the last century and a half the Act has been seen as a morally justified right on the part of dependants and a valuable measure of social welfare. It suffers, and has always suffered, from major difficulties which in the main have been resolved on the basis of pragmatism rather than theory. That is probably how things will continue. 